\title{
GAMBARAN FAKTOR RESIKO PARTUS PRETERM DI RS SMC KABUPATEN TASIKMALAYA TAHUN 2016
}

\author{
Oleh : \\ Novi Endah D.S., A.Md.Keb \\ Santi Susanti, S.SiT, M.Kes
}

\begin{abstract}
ABSTRAK
Persalinan prematur merupakan penyebab utama terjadinya AKB yaitu sebesar $60-80 \%$ morbiditas dan mortalitas neonatal di seluruh dunia. Beberapa faktor yang mempengaruhi terhadap kejadian persalinan prematur adalah usia ibu, pekerjaan ibu, status gizi, kondisi sosio-ekonomi, riwayat persalinan sebelumnya, paritas, jarak kelahiran, antenatal care, dan penyakit kehamilan. Penelitian yang dilakukan di Rumah Sakit Singaparna Medika Citra Utama (RS SMC) diperoleh kasus kejadian partus preterm pada tahun 2016 sebanyak 506 orang $(25,20 \%)$ dari jumlah ibu yang melahirkan sebanyak 2008. Tujuan penelitian ini adalah untuk mendapatkan gambaran faktor resiko partus preterm di RS SMC Singaparna Kabupaten Tasikmalaya tahun 2016.

Metode penelitian ini menggunakan deskriptif dengan pendekatan restrospektif. Subjek penelitian ini adalah seluruh ibu yang melahirkan partus premature tahun 2016 sebanyak 506 orang dengan sampel menggunakan simple random sampling sebanyak 84 orang. Teknik analisa data menggunakan analisis univariat.

Hasil penelitian menunjukkan bahwa persalinan prematur pada ibu bersalin ada pada kategori preterm yaitu sebesar $63,1 \%$, rata-rata umur ibu 28 tahun, paritas ada pada kategori multipara sebesar 53,6\%, KPSW ada pada kategori tidak terjadi KPSW sebesar $69,0 \%$, tidak terjadi gemeli sebesar $86,9 \%$, tidak terjadi preeklamsia sebesar $69,0 \%$, tidak terjadi ekslamsia sebesar $95,2 \%$, tidak terjadi plasenta previa sebesar $86,9 \%$, tidak terdapat penyakit yang menyertai sebesar $94,0 \%$, tidak mempunyai riwayat persalinan preterm sebesar 77,4\%.

Kesimpulan dari penelitian ini adalah bahwa faktor penyebab terjadinya persalinan adalah umur, paritas, KPSW, gameli, preeklamsia, eklamsia, plasenta previa, penyakit yang menyertai, dan riwayat persalinan prematur. Hendaknya bidan memberikan pelayanan ANC secara terpadu sesuai dengan pedoman agar dapat mendeteksi secara dini faktor resiko terjadinya partus preterm.
\end{abstract}

A. Abstrak

\section{Kata Kunci : Faktor Resiko, Partus preterm}




\section{B. Pendahuluan}

Di seluruh dunia terdapat sekitar 10-20\% persalinan prematur, lebih dari $60 \%$ persalinan prematur terjadi di Afrika dan Asia Selatan. Di Amerika Serikat setiap tahun sekitar 4 juta bayi yang lahir prematur dan diperkirakan sekitar 10,7-12,5\% wanita hamil di AS akan mengalami kelahiran prematur spontan, $40 \%$ diantaranya terjadi setelah kontraksi prematur (Lockwood, 1999). Sekitar 7\% dari semua kelahiran hidup mempunyai berat badan lahir rendah dan sekitar $20 \%$ di antaranya terjadi pada bayi kulit putih, $13 \%$ di antara bayi kulit hitam (Ananth, 2006). Di Eropa persalinan prematur berkisar antara 5-9\%, dan dalam 3 dekade terakhir meningkat karena indikasi medis baik pada ibu atau janin (Lawn, 2007; Goldenberg, 2008). Sebanyak 3$4 \%$ persalinan tersebut terjadi pada usia 34 minggu, sedangkan di Singapore angka kejadian persalinan prematur berkisar 6,7\%. Kejadian persalinan prematur di Indonesia berkisar antara 15-19 \%, di Bandung sebesar 9,9\%, (Effendi, 2001).

Berdasarkan hasil Survei Demografi dan Kesehatan Indonesia (SDKI) tahun 2012, angka Kematian Neonatus (AKN) pada tahun 2012 sebesar 19 per 1.000 kelahiran hidup. Angka ini sama dengan AKN berdasarkan SDKI tahun 2007 dan hanya menurun 1 point dibanding SDKI tahun 2002-2003 yaitu 20 per 1.000 kelahiran hidup. Target Rencana Pembangunan Jangka Menengah Nasional (RPJMN) tahun 2019 adalah AKB sebesar 24 per 1000 kelahiran hidup (Depkes, 2015).

Persalinan prematur merupakan penyebab utama terjadinya AKB yaitu sebesar $60-80 \%$ morbiditas dan mortalitas neonatal di seluruh dunia. Indonesia merupakan urutan kelima dari seluruh dunia yang memiliki angka kejadian prematur sekitar 19\% dan merupakan penyebab utama kematian perinatal. AKB di Provinsi Jawa Barat dari 45,69 per 1000 kelahiran hidup tahun 2000, pada tahun 2006 menurun menjadi 40,26 per 1000 kelahiran hidup. Data hasil Survey Demografi dan Kesehatan Indonesia (SDKI) 2007 menunjukkan AKB di Provinsi Jawa Barat sebesar 39 per 1000 kelahiran hidup, tahun 2010 menurun menjadi 36 26 per 1000 kelahiran hidup. dan tahun 2012 AKB di Provinsi Jawa Barat mengalami penurunan menjadi 30 per 1000 kelahiran hidup.

Beberapa faktor yang mempengaruhi terhadap kejadian persalinan prematur menurut Krisnandi (2009) dalam Rahmawati (2013) adalah usia ibu, pekerjaan ibu, status gizi, kondisi sosio-ekonomi, riwayat persalinan sebelumnya, paritas, jarak kelahiran, antenatal care, dan penyakit kehamilan.

Studi pendahuluan yang peneliti lakukan di Rumah Sakit Singaparna Medikacitra Utama (RS SMC) diperoleh kasus kejadian partus preterm pada tahun 2016 sebanyak 506 orang $(25,20 \%)$ dari jumlah ibu yang melahirkan sebanyak 2008. Jumlah kematian bayi sebanyak 68 orang dengan rincian BBLR sebanyak 4 orang $(5,88 \%)$, BBLSR sebanyak 33 orang (48,53\%), Asfiksia sebanyak 19 orang $(27,94 \%)$, IUFD sebanyak 9 orang $(13,24 \%)$, sianosis sebanyak 1 orang $(1,47 \%)$, dan kelainan kongenital sebanyak 2 orang $(2,94 \%)$.

\section{Metode Penelitian}

Jenis penelitian yang digunakan dalam penelitian ini adalah jenis penelitian deskriftip. Penelitian ini 
telah dilaksanakan pada bulan April tahun 2017 selama 2 minggu dari mulai tanggal 19-30 April 2017. Penelitian telah dilaksanakan di RS SCM Kabupaten Tasikmalaya. Populasi dalam penelitian ini adalah seluruh ibu yang melahirkan dengan partus preterm yaitu sebanyak 506 orang. Teknik pengambilan sampel dalam penelitian ini adalah simple random sampling.

Teknik pengumpulan data menggunakan data sekunder, dengan cara merekap dari laporan rekam medik melalui daftar checklist mengenai faktor resiko terjadinya persalinan preterm meliputi umur, paritas, KPSW, plasenta previa, preeklamsia, eklamsia, penyakit ibu, riwayat partus preterm dan gemeli di Rumah Sakit SMC Kabupaten Tasikmalaya tahun 2016. Analisis data yang digunakan dalam penelitian ini adalah analisis univariat, menggunakan rumus persentase menurut Arikunto (2010) sebagai berikut :

$\mathrm{P}=\frac{\mathrm{n}}{\mathrm{N}} \times 100 \%$

Dimana :

$\mathrm{n}=$ Jumlah responden berdsarkan kategori

$\mathrm{N}=$ Jumlah seluruh sampel

$100 \%=$ Bilangan tetap

$\mathrm{P}=$ Persentase

\section{Hasil penelitian}

\section{a. Persalinan Prematur}

Distribusi

mengenai persalinan

frekuensi

adalah sebagai berikut:

Tabel 5.1
Distribusi Frekuensi Persalinan Prematur pada Ibu Bersalin Di RS SMC Kabupaten Tasikmalaya Tahun 2016

\begin{tabular}{ccc}
\hline Kategori & F & \% \\
\hline Preterm (33-37 mg) & 53 & 63,1 \\
Very Preterm (28-32 mg) & 27 & 32,1 \\
Extremely Preterm & 4 & 4,8 \\
(20-27 mg) & & \\
\hline Jumlah & 84 & 100 \\
\hline
\end{tabular}

Berdasarkan $\quad$ Tabel $\quad 5.1$ menunjukkan bahwa sebagian besar persalinan prematur pada ibu bersalin di RS SMC Kabupaten Tasikmalaya tahun 2016 sebagian besar ada pada kategori preterm yaitu sebanyak 53 orang $(63,1 \%)$

\section{b. Umur}

Distribusi frekuensi mengenai umur ibu adalah sebagai berikut:

Tabel 5.2

Gambaran Umum Umur Ibu Bersalin yang Mengalami Persalinan Prematur Di RS SMC Kabupaten Tasikmalaya Tahun 2016

\begin{tabular}{ccccc}
\hline $\mathbf{N}$ & Min & Max & Rerata & SD \\
\hline 84 & $\begin{array}{c}14 \\
\text { tahun }\end{array}$ & $\begin{array}{c}49 \\
\text { tahun }\end{array}$ & 28 tahun & 7,7 \\
\end{tabular}

Tabel 5.2 menunjukkan bahwa ratarata umur ibu bersalin 28 tahun

Tabel 5.3

Distribusi Frekuensi Umur Ibu Bersalin yang Mengalami Persalinan Prematur Di RS SMC Kabupaten Tasikmalaya Tahun 2016

\begin{tabular}{ccc}
\hline Kategori & Frekuensi & Persentase \\
\hline$<20$ Tahun & 8 & 9,5 \\
20-35 Tahun & 61 & 72,6 \\
$>$ 35 Tahun & 15 & 17,9 \\
\hline Jumlah & 84 & 100 \\
\hline
\end{tabular}

Berdasarkan Tabel $\quad 5.3$ menunjukkan bahwa sebagian besar umur ibu bersalin yang mengalami 
persalinan prematur sebagian besar ada pada kategori umur 20-35 tahun yaitu sebanyak 61 orang $(72,6 \%)$.

\section{c. Paritas}

Distribusi frekuensi mengenai paritas ibu bersalin adalah sebagai berikut:

Tabel 5.5

Distribusi Frekuensi Paritas Ibu Bersalin yang Mengalami Persalinan prematur Di RS SMC

Kabupaten Tasikmalaya Tahun 2016

\begin{tabular}{ccc}
\hline Kategori & Frekuensi & Persentase \\
\hline Primipara & 32 & 38,1 \\
Multipara & 45 & 53,6 \\
Grandemultipara & 7 & 8,3 \\
\hline Jumlah & 84 & 100 \\
\hline
\end{tabular}

Berdasarkan Tabel 5.5 menunjukkan bahwa sebagian besar paritas ibu bersalin sebagian besar ada pada kategori multipara yaitu sebanyak 45 orang $(53,6 \%)$

\section{d. Ketuban Pecah Sebelum Waktunya (KPSW) \\ frekuensi}

Distribusi

mengenai ketuban pecah sebelum waktunya adalah sebagai berikut :

Tabel 5.6

Distribusi Frekuensi KPSW Ibu Bersalin yang Mengalami Persalinan Prematur Di RS SMC Kabupaten Tasikmalaya Tahun 2016

\begin{tabular}{ccc}
\hline Kategori & Frekuensi & Persentase \\
\hline Tidak & 58 & 69,0 \\
Ya & 26 & 31,0 \\
\hline Jumlah & 84 & 100 \\
\hline
\end{tabular}

Berdasarkan Tabel 5.6 menunjukkan bahwa sebagian besar KPSW pada ibu bersalin yang mengalami persalinan prematur sebagian besar ada pada kategori tidak terjadi KPSW yaitu sebanyak 58 orang $(69,0 \%)$. e. Gemeli

Distribusi frekuensi mengenai gemeli adalah sebagai berikut :

Tabel 5.7

Distribusi Frekuensi Gemeli pada Ibu Bersalin yang Mengalami Persalinan Prematur Di RS SMC

Kabupaten Tasikmalaya Tahun 2016

\begin{tabular}{ccc}
\hline Kategori & Frekuensi & Persentase \\
\hline Tidak & 73 & 86,9 \\
Ya & 11 & 13,1 \\
\hline Jumlah & 84 & 100 \\
\hline
\end{tabular}

Berdasarkan Tabel 5.7 menunjukkan bahwa sebagian kecil ada pada kategori terjadi gemeli yaitu sebanyak 11 orang $(13,1 \%)$.

\section{f. Preeklamsia}

Distribusi frekuensi mengenai kejadian preeklamsia adalah sebagai berikut :

Tabel 5.8

Distribusi Frekuensi Preeklamsia pada Ibu Bersalin yang Mengalami Persalinan Prematur Di RS SMC

Kabupaten Tasikmalaya Tahun 2016

\begin{tabular}{ccc}
\hline Kategori & Frekuensi & Persentase \\
\hline Tidak & 58 & 69,0 \\
Ya & 26 & 31,0 \\
\hline Jumlah & 84 & 100
\end{tabular}

Berdasarkan Tabel 5.8 menunjukkan bahwa sebagian kecil ada pada kategori terjadi preeklamsia yaitu sebanyak 26 orang $(31,0 \%)$.

\section{g. Ekslamsia}

Distribusi frekuensi mengenai kejadian ekslamsia adalah sebagai berikut :

Tabel 5.9 
Distribusi Frekuensi Ekslamsia pada Ibu Bersalin yang Mengalami Persalinan Prematur Di RS SMC

Kabupaten Tasikmalaya Tahun 2016

\begin{tabular}{ccc}
\hline Kategori & Frekuensi & Persentase \\
\hline Tidak & 80 & 95,2 \\
Ya & 4 & 4,8 \\
\hline Jumlah & 84 & 100 \\
\hline
\end{tabular}

Berdasarkan Tabel 5.9 menunjukkan bahwa sebagian kecil ada pada kategori terjadi eklamsia yaitu sebanyak 4 orang $(4,8 \%)$.

\section{h. Plasenta Previa}

Distribusi

frekuensi

mengenai kejadian plasenta previa adalah sebagai berikut :

Tabel 5.10

Distribusi Frekuensi Plasenta Previa pada Ibu Bersalin yang Mengalami Persalinan Prematur Di RS SMC Kabupaten Tasikmalaya Tahun 2016

\begin{tabular}{ccc}
\hline Kategori & Frekuensi & Persentase \\
\hline Tidak & 73 & 86,9 \\
Ya & 11 & 13,1 \\
\hline Jumlah & 84 & 100 \\
\hline
\end{tabular}

Berdasarkan Tabel 5.10 menunjukkan bahwa sebagian kecil ada pada kategori terjadi plasenta previa yaitu sebanyak 11 orang $(13,1 \%)$.

\section{i. Penyakit yang Menyertai}

Distribusi frekuensi mengenai kejadian penyakit yang menyertai pada ibu bersalin yang mengalami persalinan prematur adalah sebagai berikut :

\section{Distribusi Frekuensi Penyakit yang Menyertai pada Ibu Bersalin yang Mengalami Persalinan Prematur Di RS SMC Kabupaten Tasikmalaya Tahun 2016}

\begin{tabular}{ccc}
\hline Kategori & Frekuensi & Persentase \\
\hline Tidak & 82 & 97,6 \\
Ya & 2 & 2,4 \\
\hline Jumlah & 84 & 100 \\
\hline
\end{tabular}

Berdasarkan Tabel 5.11 menunjukkan bahwa sebagian kecil ada pada kategori terdapat penyakit yang menyertai yaitu sebanyak 2orang $(2,4 \%)$.

\section{j. Riwayat Partus Preterm}

Distribusi frekuensi mengenai riwayat partus preterm adalah sebagai berikut :

Tabel 5.12

Distribusi Frekuensi Riwayat Partus Preterm pada Ibu Bersalin yang Mengalami Persalinan Prematur Di RS SMC Kabupaten Tasikmalaya Tahun 2016

\begin{tabular}{ccc}
\hline Kategori & Frekuensi & Persentase \\
\hline Tidak & 65 & 77,4 \\
Ya & 19 & 22,6 \\
\hline Jumlah & 84 & 100 \\
\hline
\end{tabular}

Berdasarkan Tabel $\quad 5.12$ menunjukkan bahwa sebagian kecil ada pada kategori terdapat riwayat partus preterm yaitu sebanyak 19 orang $(22,6 \%)$.

\section{E. Pembahasan}

\section{Faktor umur}

Berdasarkan hasil penelitian menunjukkan bahwa sebagian besar umur ibu bersalin yang mengalami persalinan prematur di RS SMC Kabupaten Tasikmalaya tahun 2016 sebagian besar ada pada kategori umur 20-35 tahun yaitu sebanyak 61 orang $(72,6 \%)$, sedangkan yang

Tabel 5.11 
berumur $<20$ tahun sebanyak 8 orang $(9,5 \%)$ dan seluruhnya mengalami paritas 1 .

Kejadian partus prematur pada ibu dengan usia $<20$ tahun disebabkan karena secara fisik dan psikis masih kurang, misalnya dalam perhatian untuk pemenuhan kebutuhan zat-zat gizi selama kehamilannya. Pada kehamilan diusia kurang dari 20 tahun secara fisik dan psikis masih kurang, misalnya dalam perhatian untuk pemenuhan kebutuhan zat-zat gizi selama kehamilannya. Sedangkan pada usia 35 tahun merupakan salah satu faktor predisposisi terjadinya kelahiran prematur. Hal ini dikarenakan pada usia 35 tahun fungsi dari alat reproduksi sudah menurun sehingga akan mempengaruhi kehamilannya. Sedangkan kejadian partus prematur pada ibu dengan usia reproduksi sehat juga dipengaruhi oleh berbagai faktor lain yang mempengaruhi seperti faktor idiopatik yang apabila penyebab partus prematur tidak dapat diterangkan, faktor Iatrogenik yang apabila kelangsungan kehamilan dapat membahayakan janin ataupun ibu sehingga menyebabkan persalinan prematur buatan, kemudian faktor sosio demografik seperti kecemasan, stress, pekerjaan ibu, perilaku ibu, ataupun kondisi sosio ekonomi, serta faktor maternal seperti inkompetensi serviks, pernah mengalami partus prematur, interval kehamilan, kehamilan multijanin, ataupun karena infeksi.

Kondisi ini sejalan dengan penelitian yang dilakukan Trihardiani (2011) yang menyatakan bahwa persalinan preterm banyak terjadi pada usia 20 - 35 tahun, yaitu sebanyak $81,6 \%$, dan yang berusia 35 tahun sebanyak 18,4\%.

2. Paritas

Berdasarkan hasil penelitian menunjukkan bahwa sebagian besar paritas ibu bersalin yang mengalami persalinan prematur di RS SMC Kabupaten Tasikmalaya tahun 2016 sebagian besar ada pada kategori multipara yaitu sebanyak 45 orang $(53,6 \%)$.

Hal ini sejalan dengan penelitian yang dilakukan oleh Ariana Novi (2011) menyatakan bahwa proporsi responden ibu bersalin multiparitas pada persalinan prematur (kasus) sebanyak $26(63,4 \%)$ sedangkan pada persalinan normal (kontrol) sebanyak 29 (70,7\%). Hasil ini menunjukkan bahwa ibu bersalin multiparitas pada persalinan prematur dan persalinan normal hampir sama banyaknya. Paritas lebih dari empat juga berisiko mengalami komplikasi serius, seperti perdarahan dan infeksi yang akan mengakibatkan adanya kecenderungan bayi lahir dengan kondisi preterm bahkan terjadinya kematian ibu dan bayi (Trihardiani, 2011).

\section{Ketuban Pecah Sebelum Waktunya (KPSW)}

Berdasarkan hasil penelitian menunjukkan bahwa sebesar $31,0 \%$ ibu bersalin yang mengalami persalinan prematur di RS SMC Kabupaten Tasikmalaya tahun 2016 terjadi ketuban pecah sebelum waktunya (KPSW).

Ketuban pecah sebelum waktunya (KPSW) didefinisikan sebagai pecahnya ketuban sebelum waktunya melahirkan. Ketuban pecah sebelum waktunya kebanyakan terjadi pada usia kehamilan antara 34-36 minggu, dan sering disertai dengan komplikasi infeksi perinatal dan gawat janin, sehingga ketuban pecah sebelum waktunya dapat menyebabkan 
morbiditas dan mortalitas perinatal yang lebih besar dari pada yang disebabkan oleh kehamilan preterm. Insidensi KPD berkisar antara 8- 10\% dari semua kehamilan. Pada kehamilan aterm insidensinya bervariasi antara 6-19\%. Sedangkan pada kehamilan preterm insidensinya $2 \%$ dari semua kehamilan. Hampir semua KPD pada kehamilan preterm akan lahir sebelum aterm atau persalinan akan terjadi dalam satu minggu setelah selaput ketuban pecah. Sekitar 85\% morbiditas dan mortalitas perinatal disebabkan oleh prematuritas. KPD berhubungan dengan penyebab kejadian prematuritas dengan insidensi 30- 40\% (Sualman, 2009).

Hal ini sejalan dengan penelitian yang dilakukan oleh $\mathrm{Ni}$ Wayan Raina (2013) yang menyatakan bahwa ada hubungan antara ketuban pecah dini dengan persalinan prematur sehingga perlu dilakukan penanganan dan perawatan lebih intensif dalam mengurangi kejadian morbiditas dan mortalitas pada bayi prematur.

\section{Gemeli}

Berdasarkan hasil penelitian menunjukkan bahwa sebesar $13,1 \%$ ibu bersalin yang mengalami persalinan prematur di RS SMC Kabupaten Tasikmalaya tahun 2016 tidak mengalami gemeli yaitu sebanyak 73 orang $(86,9 \%)$.

Proses persalinan pada kehamilan ganda bukan multiplikasi proses kelahiran bayi, melainkan multiplikasi dari risiko kehamilan dan persalinan (Saifuddin, 2009). Persalinan pada kehamilan kembar besar kemungkinan terjadi masalah seperti resusitasi neonatus, prematuritas, perdarahan postpartum, malpresentasi kembar kedua, atau perlunya seksio sesaria (Varney, 2007).
Berat badan kedua janin pada kehamilan kembar tidak sama, dapat berbeda 50-1000 gram, hal ini terjadi karena pembagian darah pada plasenta untuk kedua janin tidak sama. Pada kehamilan kembar distensi (peregangan) uterus berlebihan, sehingga melewati batas toleransi dan sering terjadi persalinan prematur. Kematian bayi pada anak kembar lebih tinggi dari pada anak kehamilan tunggal dan prematuritas meupakan penyebab utama (Wiknjosastro, 2007).

\section{Preeklamsia}

Berdasarkan hasil penelitian menunjukkan bahwa sebesar $31,0 \%$ ibu bersalin yang mengalami persalinan prematur di RS SMC Kabupaten Tasikmalaya tahun 2016 tidak terjadi preeklamsia yaitu sebanyak 58 orang $(69,0 \%)$. Preeklampsia adalah hipertensi yang timbul setelah usia 20 minggu kehamilan dan disertai dengan proteinuria, sedangkan eklampsia adalah preeklampsia yang disertai dengan kejang dan atau koma. Preeklampsia meningkatkan risiko terjadinya solusio plasenta, persalinan prematur, Intrauterine Growth Retardation (IUGR), dan hipoksia akut. Preeklampsia menyumbang sekitar $15 \%$ dari semua kelahiran prematur.

Preeklampsia didasari oleh beberapa teori, namun teori yang saat ini paling banyak digunakan adalah teori iskemia plasenta, radikal bebas dan disfungsi endotel. Berdasarkan teori ini terjadi kegagalan "remodeling arteri spiralis" sehingga menyebabkan plasenta mengalami iskemia dan terjadi disfungsi endotel. Spasme pembuluh darah arteriola yang menuju organ penting dalam tubuh dapat menyebabkan mengecilnya aliran darah yang menuju retroplasenta sehingga mengakibatkan gangguan pertukaran $\mathrm{CO} 2$ , O2 dan nutrisi pada janin. Hal ini 
menyebabkan terjadinya vasospasme dan hipovolemia sehingga janin menjadi hipoksia dan malnutrisi. Hipoksia menyebabkan plasenta mengtransfer kortisol dengan kadar yang tinggi ke dalam sirkulasi janin. Konsentrasi kortisol yang tinggi akan mensintesis prostaglandin yaitu protasiklin (PGE-2) yang menyebabkan timbulnya kontraksi, perubahan pada serviks dan pecahnya kulit ketuban, sehingga bayi sering terlahir premature.

Hasil penelitian ini sejalan dengan penelitian yang dilakukan oleh Widyastutik (2011) yang menyatakan bahwa preeklampsia memberikan hubungan yang signifikan $(\mathrm{p} \leq 0,05)$ dengan angka kejadian partus prematurus di RSUD Dr. Moewardi Surakarta periode bulan JanuariMaret tahun 2011.

\section{Eklamsia}

Berdasarkan hasil penelitian menunjukkan bahwa sebesar $4,8 \%$ ibu bersalin yang mengalami persalinan prematur di RS SMC Kabupaten Tasikmalaya tahun 2016 menglami ekslamsia. Eklamsia didefinisikan sebagai terjadinya kejang dan/ atau koma yang tidak dapat dijelaskan selama kehamilan atau setelah melahirkan pada pasien dengan tanda dan gejala preeklamsia.

Menurut Castro (2004), pada hipertensi aliran darah cerebral dan konsumsi oksigen lebih sedikit dibandingkan dengan wanita hamil biasa dan terdapat penurunan aliran darah dan peningkatan tahan vaskuler pada sirkulasi uteroplasenta pada pasien ekslamsia sehingga dapat menyebabkan solusio plasenta, IUFD, dan partus prematurus.

\section{Plasenta Previa}

Berdasarkan hasil penelitian menunjukkan bahwa sebesar $13,1 \%$ ibu bersalin yang mengalami persalinan prematur di RS SMC Kabupaten
Tasikmalaya tahun 2016 mengalami plasenta previa. Jenis plasenta previa yang terjadi pada ibu bersalin dengan persalinan prematur adalah plasenta previa totalis sebanyak 5 orang dan marginal sebanyak 6 orang.

Plasenta previa adalah posisi plasenta yang berada di segmen bawah uterus, baik posterior maupun anterior, sehingga perkembangan plasenta yang sempurna menutupi os serviks (Varney, 2007). Plasenta yang menutupi jalan lahir dapat menutupi seluruh osteum uteri internum, sebagian atau tepi plasenta berada sekitar pinggir osteum uteri internum (Wiknjosastro, 2007).

8. Penyakit yang Menyertai

Berdasarkan hasil penelitian menunjukkan bahwa sebesar $2,4 \%$ ibu bersalin yang mengalami persalinan prematur di RS SMC Kabupaten Tasikmalaya tahun 2016 tidak terdapat penyakit yang menyertai yaitu sebanyak 82 orang (97,6\%). Penyakit yang menyertai ibu bersalin dengan partus perterm sebanyak jantung 1 orang, dan 1 orang mengalami diabetes mellitus.

Penyakit kardiovaskular adalah sekelompok gangguan pada jantung dan pembuluh darah. Penyakit jantung/kardiovaskular terjadi pada 0,5-3 $\%$ kehamilan, yang dapat menyebabkan morbiditas dan mortalitas pada ibu hamil di dunia. Pada penyakit jantung yang disertai kehamilan, pertambahan denyut jantung dan volume sekuncup jantung dapat menguras cadangan kekuatan jantung. Payah jantung akan menyebabkan stres maternal sehingga terjadi pengaktifan aksis HPA yang akan memproduksi kortisol dan prostaglandin, kemudian mencetuskan terjadinya persalinan prematur.

Penyakit Diabetes Melitus dimana tubuh tidak bisa menghasilkan insulin 
dalam jumlah cukup, atau tubuh kurang bisa memaksimalkan penggunaan insulin. Ibu hamil dengan diabetes gestasional akan menghasilkan janin yang lebih besar, sehingga risiko bedah sesar meningkat dan mempengaruhi kesehatan janin maupun ibunya.

9. Riwayat partus preterm

Berdasarkan hasil penelitian menunjukkan bahwa sebesar $22,6 \%$ ibu bersalin mengalami persalinan prematur. Persalinan prematur dapat terjadi pada ibu dengan riwayat prematur sebelumnya (Rayburn, 2001). Menurut Oxorn (2003) risiko persalinan prematur berulang bagi wanita yang persalinan pertamanya preterm, dapat meningkat tiga kali lipat dibanding dengan wanita yang persalinan pertamanya mencapai aterm.

Wanita yang telah mengalami kelahiran prematur pada kehamilan terdahulu memiliki risiko $20 \%$ sampai 40 $\%$ untuk terulang kembali (Varney, 2007). Persalinan prematur dapat terulang kembali pada ibu yang persalinan pertamanya terjadi persalinan prematur dan risikonya meningkat pada ibu yang kehamilan pertama dan kedua juga mengalami persalinan prematur.

\section{F. Simpulan dan Saran}

Hasil penelitian dapat disimpulkan sebagai berikut :

1. Kejadian persalinan prematur pada ibu bersalin di RS SMC Kabupaten Tasikmalaya Tahun 2016 sebagian besar ada pada kategori preterm sebesar $63,1 \%$.

2. Gambaran faktor risiko ibu bersalin dengan persalinan prematur di RS SMC Kabupaten Tasikmalaya Tahun 2016 sebagian besar ada pada kategori umur reproduksi sehat. Paritas ibu sebagian besar ada pada kategori multipara sebesar. Faktor resiko Ketuban Pecah Sebelum Waktunya yaitu 31,0\%.
Berdasarkan faktor resiko preeklamsia yaitu 31,0\%. Berdasarkan faktor resiko ekslamsia yaitu 4,8\%. Berdasarkan faktor resiko plasenta previa yaitu $13,1 \%$. Berdasarkan faktor resiko penyakit yang menyertai yaitu $2,4 \%$, dan berdasarkan faktor resiko riwayat partus preterm yaitu $22,6 \%$.

\section{G. Saran}

1. Bagi Bidan

Bidan hendaknya memberikan pelayanan ANC terpadu untuk mendeteksi dini resiko partus preterem, selain itu juga memberikan penyuluhan tentang pentingnya asupan nutrisi yang baik selama kehamilan.

2. Bagi Ibu Hamil

Hendaknya ibu lebih meningkatkan wawasan mengenai kehamilan dan persalinan, sehingga ibu dapat terhindar dari persalinan prematur dan melakukan kunjungan kehamilan ke petugas kesehatan minimal 4 kali selama kehamilan, agar pertumbuhan dan perkembangan janin dapat terpantau dengan baik.

\section{H. Referensi}

Ananttr" 2006. Previous caesarean and risks of placenta previa and placental abruption Obstet Gynecol. April 107 (a) pp. 771-8. Available <http i/www.ncbi.nlm.nih. gov/entrez/query. fcgi ?db:pubmed\&cmd:Retrieve\&dopFAbstra...> [Accessed 7 Januari 20171.

Bobalq 2004. Buht Ajw Keperawatan Maternitas. Edisi 4. Jakarta: EGC

Cunningham,2006. Obstetri Williams Volume /. Jakarta: EGC 
Dian Rahmawati, 2013. Fahorfahor yang nempengaruhi terjadinya persalinan preterm di RSUD dr. Moewardi Surakarta. Jurnal Penelitian. Diakses Tanggal 24 Januari 2017.

Goldenberg, 2008.

Epidemiologt and Causes of Preterm Birth. The Lancet. [arn,2002. Prediction and Early Detection of Preterm Labor. The American College of Obstetricians and Gynecologists [intemet]. 2003 [cited 2014 Feb I 11.

JNPK-K\& 2007. Asuhan

Persalinan Normal. Depkes RI. Jakarta

Koucky, 2009.

Pathopltysiologt of Preterm Labour.20A9 ;110 (1)

Krisnadi, 2009. Prematuritas.

Bandung: Refika Aditama

Kurniasill 2009. Persalinan

Prematur. Available

http://himapid.com/2009/1

$0 /$ persatinan-prematur.html [accessed Januari 2017J

Lockwood, 1999. Leveraging Ernployee Engagement for Competitive Advantage. Joumal of Human Resources Management

Manuaba 1998. Gawat Dorurat Obstetri Ginekologo dan Obstetri Ginekologi, Jakarta : EGC

Norwitz \& Schorge, 2008. At Glance Obstetri dan Ginekologi. Edisi II. Penerbit, Erlangga, Jakarta. Notoannodjo, 2012. Metodologi penelitian Kesehatan Jakarta: Rineka Cipta

Nursalam, 2008. Konsep dan Penerapan Metodologi Penelitian llmu Keperawatan. Jakarta: Salemba Medika.

Oxorn, 2003. Pelayanan Obstetri dan Ginekologi. Jakafia: EGC
Rayburr $\backslash$ 2001. Obsteti \& Ginekologi. Jakarta: Widya Medika

Rose dan Marie, 2009. Maternal anernia and preterm birth: a prospective cohort study.Int. J. Epidemiol. 38 (5):1380- 1389

Saifuddin 2009. Buht Acuan Pelayanan Keselwtan Maternal dan Neonatal. Jakarta: YBPSP

SumaralU 2008. Asuhan Kebidanan Pada lbu Bersalin Yogyakarta: Fitramaya

Usman, Effendi, 2001. Tinjauan kasus persalinan prematur di RSHS tahtm 1998-2000. PTPPOGI )(II, Palembang 2001.

Vamey,2008. BufuAjm Asuhan Kebidanan Edisi 4. Jakarta: EGC

Widyastuti, dklg 2009. Kesehatan Reproduksf. Yogyakana: Fitramaya

Wiknjosasho, 2009. Ilmu Ke bidonon Sarw ono Prm,ir ohwdj o. Jakarta: )TBPSP

Zabrotul Ai,mah, 2012. Hubungan Antara Pwitas dengan Kejadtan Pqrtus Kejadian

Partus Preterm di RSUD dr. Moewwdi Suraksrta. Jurnal PEnelitian. Diakses Tanggal 24 Jamanz017. 